\title{
Teaching Information Systems Students Ethics of Responsibility for Technology Design Practices
}

\author{
Carolien van den Berg \\ ${ }^{1}$ University of the Western Cape, South Africa
}

\begin{abstract}
.
The paper presents a work-in-progress project that explores the design of teaching and learning principles that will foreground an ethic of responsibility among Information Systems (IS) students. We are experiencing an urgent need to address the inequality and sustainability challenges of our time. It requires the exploration of new, responsible ways of operating, researching, and innovating that enable society to respond to these challenges. Our role in Higher Education (HE) is to prepare students to engage in Responsible Research and Innovation (RRI). Technology such as machine learning, artificial intelligence, algorithms, big data, automation, and robotics are currently being applied in a wide range of fields, and designers are just beginning to understand the implications of these developments for design practice. Information Systems scholars need a deeper understanding of their role as designers of future technologies and the ethical, legal, and commercial controversies these developments are calling into question. Technology and innovation are formidable shapers of human lives and society. It is therefore very important to think about what we are doing to ourselves and to each other by means of technology. There is limited research about the study of values and ethics within Information Systems education. The available research mainly focuses on compliance and procedure rather than a broader view that encourages deeper interrogation about societal impact. This prompted a design-based research (DBR) study over three iterations to develop design principles in order to teach IS students ethics of responsibility towards the design of technology.
\end{abstract}

Keywords: design based research; ethical principles; social innovation; scenario planning; technology design. 


\title{
World Conference on Teaching and Education
}

\author{
18-20 October, 2019 Budapest, Hungary
}

\section{Introduction}

We are living in a turbulent time characterised by inequality and grand sustainability challenges increasingly referred to as the Anthropocene (Gibson et al. 2015). The functioning of the ecosystems and the well-being of people are at risk requiring an urgent appeal to address issues such as climate change, resource scarcity, financial crisis, social injustice, ubiquitous technologies amongst others. We need a shift from the current models driving our society towards a more responsible approach relating to people and the planet in operating, researching, and innovating (Tassone et al., 2018).

We have the responsibility in Higher Education to urgently address such pressing issues via greater connectivity between the academic community and the rest of society. However, we are experiencing a miss-match between HEIs and society placing us at the crossroads, having to choose between the business as usual path of commodification of knowledge and learning focused on the "well-being of the economy, or the innovative path of socio-ecological transition requiring new responsible forms of collaborative research and learning and alternative capabilities and values that contribute to the well-being of planet and people" (Tassone et al., 2018: 338). Against this backdrop and with further pressures posed by the $4^{\text {th }}$ Industrial Revolution, a project with students in Information Systems (IS) was designed to determine design principles that will enable responsible research and innovation (RRI).

The 4th Industrial Revolution is typified as a dynamic era of rapid change, complexity, fluidity and ubiquity within all realms of our everyday existence. Technology such as machine learning, artificial intelligence, algorithms, big data, automation and robotics are currently being applied in a wide range of fields, and designers are just beginning to understand the implications of these developments for design practice (Price, Matthews \& Wrigley, 2018). The impact of these technologies on society, communities and individuals is presenting challenges to the traditional conceptualisation of design as a human-focused endeavour (Brynjolfsson, Mitchell \& Rock, 2018).

It is becoming more and evident that IS scholars need a deeper understanding of their role as designers of future technologies, how the technologies they design actually work and the ethical, legal, and commercial controversies these developments are calling into question. Technology and innovation are formidable shapers of human lives and society. It is therefore very important to think about what we are doing to ourselves and to each other by means of technology (van den Hoven, 2017).

There are very limited research about the study of values and ethics within IS education. The available research mainly focuses on compliance and procedure rather than a broader view that encourages deeper interrogation about societal impact (Philbeck, Davis \& Engtoft Larsen, 2018). There is an urgent call for educators to improve future citizens and professionals through the study of values and ethics (ibid, 2018). 


\section{World Conference on Teaching and Education}

\section{8-20 October, $2019 \quad$ Budapest, Hungary}

The paper commences with a review of the literature in order to formulate draft design principles that can inform the teaching and learning environment to teach IS students ethics of responsibility towards the design of technology. The methodology and results from a pilot study are subsequently presented that resulted in the updated principles that will be further tested and refined.

\section{A review of the literature}

The digital world is presenting us with a fast-moving era of complexity, fluidity and ubiquity within our everyday reality where we face knowledge creation by new actors that are increasingly (artificially) intelligent, automated, difficult to observe and complex to analyse and understand. Technologies continue to be seen as part of the solution to many complex global challenges in the 21st century. Technology innovations are capable of taking society forward in an inclusive, sustainable and positive way, if the right approach to their development is taken (Philbeck et al., 2018). However, the design of these innovations is informed by the world views and values of its makers. Therefore a deep awareness of particular configurations of "social, ethical, and political values" needs to be embedded in the design at an early stage (Van den Hoven, 2017: 65).

There needs to be a shift towards future focused design practices with an emphasis on the process of design because technologies such as artificial intelligence have a profound impact on the world and one cannot wait until they are fully developed and deployed. Ethical principles need to be embedded in technology design through a process of reflective, deliberative and participatory approaches that focus on processes and outcomes (Philbeck et al., 2018).

Monteiro, Leite and Rocha (2018) postulate ethical education as the pillar of the future role of higher education. The argue in favour of broad and multidisciplinary training that enables an analysis informed by different points of view, using different sets of knowledge via multidisciplinary teams conducting projects with industry. Teams should analyse the impact of technology on complex systems, particularly social, economic and political systems. Furthermore, Walsham (2012: 89) makes and important case for IS students to have a much stronger "ethical agenda of making a better world and a sharper critical agenda towards existing approaches and power structures". As such, students need to be exposed to various design considerations adapted from (Mulvenna, Boger \& Bond, 2017: 53):

- Design to support the people who will be using the product or service by engendering empathy for users.

- Provide enough information for people to make informed decisions at every stage about whether, when, and how to use the product or service.

- Balance appropriate privacy and security with equitable access by as many systems and people as possible, globally.

- Complement differing needs, abilities, viewpoints and morals.

- Aim for economically, environmentally, and socially sustainable designs.

- Integrate planning for how to handle failure, including transparency and reporting. 


\section{World Conference on Teaching and Education}

\section{8-20 October, 2019 Budapest, Hungary}

- Be realistic about what is possible and needed.

Technology design requires a systemic view with an understanding of the moral components of technologies and an inclusive process for stakeholder engagement requiring new curricula and programmes of study. Foresight tools, such as horizon scanning and scenario planning, can be extremely helpful in anticipating how a technology may influence individual behaviour (Philbeck et al., 2018). This is supported by Tassone et al (2018) who argue in favour of a broader notion of responsibility that allows for a deeper reflection about ways of doing and being, and also allows for the cultivation of social values and for socially and planetary relevant responses. The challenging conditions of our time call for human values that return us to our basic obligation to care for others and the earth, and to permeate our endeavours with that sense of care, within and beyond the specific role one plays in society at a given point in time. As such, it is recommended to have an ethic of care perspective interwoven in the design of the learning environment.

Joan Tronto's ethics of care (2013) is a useful framework to reveal moral elements and perspectives on human interaction. Tronto's work is informed by a relational ontology that is holistic and interdependent and systemic in nature. It highlights nuances in the moral dimension of interactions between people, the environment and society at large. It sheds light on issues of power, authority and caring in collaborative engagements.

Figure 1, depicts the elements that need to be included in the draft of the design principles.

Figure 1: Responsible research innovation framework

$\begin{gathered}\text { Future studies ability } \\ \text { Future orientated } \\ \text { ethical abilities } \\ \text { Pro-active }\end{gathered}$
$\begin{gathered}\text { Navigate complexity or } \\ \text { wickedness } \\ \text { Adaptability } \\ \text { Agency }\end{gathered}$




\section{World Conference on Teaching and Education}

\section{8-20 October, 2019 Budapest, Hungary}

Source: Adapted from (Tassone, O’Mahony, McKenna, Eppink, \& Wals, 2018)

Figure 1 is expanded in Table 1 to contain an outline of the draft design principles that were incorporated in the course design.

Table 1: Draft design principles

\begin{tabular}{|l|l|l|}
\hline $\begin{array}{l}\text { Implement a } \\
\text { formal process } \\
\text { of reflection via } \\
\text { student blogs }\end{array}$ & $\begin{array}{l}\text { Provide guidelines via rubrics on content to be included in the blogs, } \\
\text { such as weekly reflections on what has been learned, what they } \\
\text { enjoyed and what they did not enjoy, as well as other exercises that } \\
\text { will make students more comfortable with futurist design principles. } \\
\text { Build awareness of sustainability, social justice, ethics of care and }\end{array}$ \\
\hline
\end{tabular}

\begin{tabular}{|c|c|}
\hline & $\begin{array}{l}\text { make that a requirement of student projects. } \\
\text { - Include a task at the end of the semester in the blogs where students } \\
\text { need to reflect on the challenges that technological and } \\
\text { environmental transformations are posing for their future. They need } \\
\text { to question their future roles as designers of complex systems for } \\
\text { example the power distribution across human, machines, and natural } \\
\text { systems. } \\
\text { A further exercise should be critical reflection on the question of how } \\
\text { societies should govern technologies that pose ethical challenges and } \\
\text { may have undesirable influences on societal priorities. Assess the } \\
\text { reflection process using clear guidance in the rubric in terms of } \\
\text { expected outcomes. } \\
\text { Lecturer and peers must provide formative feedback to students on } \\
\text { their blogs during the semester, and the formal assessment of all } \\
\text { blogs occurs at the end of the semester. }\end{array}$ \\
\hline $\begin{array}{l}\text { Incorporate a } \\
\text { future oriented } \\
\text { agenda }\end{array}$ & $\begin{array}{l}\text { Apply foresight tools, such as horizon scanning and scenario } \\
\text { planning. } \\
\text { Incorporate multi-modal pedagogies to create an environment to } \\
\text { allow for free design to take place. } \\
\text { Make students aware of their design imprint on society and take them } \\
\text { through the process of design thinking, where they start with user } \\
\text { needs and combine user stories with empathy maps and/or personas. } \\
\text { They need to become aware of the wider imprint that they have on } \\
\text { society and that the user can be human or nonhuman with the } \\
\text { systemic implications thereof. } \\
\text { They then follow the process of prototyping, testing and repeating } \\
\text { the process where required. }\end{array}$ \\
\hline
\end{tabular}




\section{World Conference on Teaching and Education}

\section{8-20 October, 2019 \\ Budapest, Hungary}

\begin{tabular}{|c|c|}
\hline & $\begin{array}{l}\text { - Students need exposure to their overall impact in the design process } \\
\text { to consider ethical implications such as justice, equity, privacy, } \\
\text { autonomy, safety and security, sustainability and wellbeing amongst } \\
\text { others. The concept of responsible innovation should be embedded in } \\
\text { the design rollout (van den Hoven 2017). } \\
\text { Exposure to the future to enable students to understand the processes } \\
\text { of technological development by asking what long-term future is } \\
\text { wanted, and then how to orient technological development towards } \\
\text { achieving it. } \\
\text { Both the lecturer and the students need to learn to embrace the } \\
\text { uncertainties and open-ended nature of design problems and to learn } \\
\text { to accept failure. Lecturer should stress the importance of productive } \\
\text { failure and assist students to correct prototypes and encourage them } \\
\text { to try new things and new ways of doing. }\end{array}$ \\
\hline $\begin{array}{l}\text { Provide } \\
\text { opportunities } \\
\text { for students to } \\
\text { find their own } \\
\text { solutions }\end{array}$ & $\begin{array}{l}\text { - When the students struggle and sometimes fail to find a solution, they } \\
\text { gain a deeper insight into the problem and its elements. } \\
\text { - Structure the class to enable each team to work together, i.e. around a } \\
\text { table or in a breakaway venue if possible. } \\
\text { - Use lecture times to allow students to explore, investigate and } \\
\text { present findings. The future can be better confronted by opening our } \\
\text { minds and learning to consider different viewpoints. }\end{array}$ \\
\hline & $\begin{array}{l}\text { Do not put too much structure in place; some background material } \\
\text { ought to be provided prior to the lecture via, for example, voiceover } \\
\text { PowerPoint and videos, and lectures can be used to practically } \\
\text { explore this further and incorporate the relevant areas into capstone } \\
\text { projects. } \\
\text { Allow students to discover their own answers by accessing several } \\
\text { different sources and experimenting with different techniques to } \\
\text { become comfortable with pivoting, adapting and changing. } \\
\text { Students ought to play a large role in shaping the course by setting } \\
\text { their own deadlines, determining leadership roles and managing } \\
\text { group dynamics. }\end{array}$ \\
\hline
\end{tabular}

\section{Methods}

In Design Based Research (DBR), the researcher collaborates with participants and other stakeholders to improve teaching and learning practices in an interactive, systematic, flexible and iterative way within real-world settings (Herrington \& Reeves, 2011). It is important to start with a review of the literature and interaction with different stakeholders in order to base the initial design on sound theoretical principles. In the iterative cycles, the theory is enriched and updated based on the data collected in each cycle and the experiences of the designers (Herrington \& Reeves, 2011). The literature review and an initial design were discussed above and a summary depicted in Figure 1 and Table 1. 


\section{World Conference on Teaching and Education}

\section{8-20 October, 2019 Budapest, Hungary}

A four phased DBR approach will be applied as depicted in Figure 2. The four phases are described in the sections below and the final outcome is six design principles that will be applied during the three iterations.

Figure 2: Predictive and design-based research approaches in educational technology research

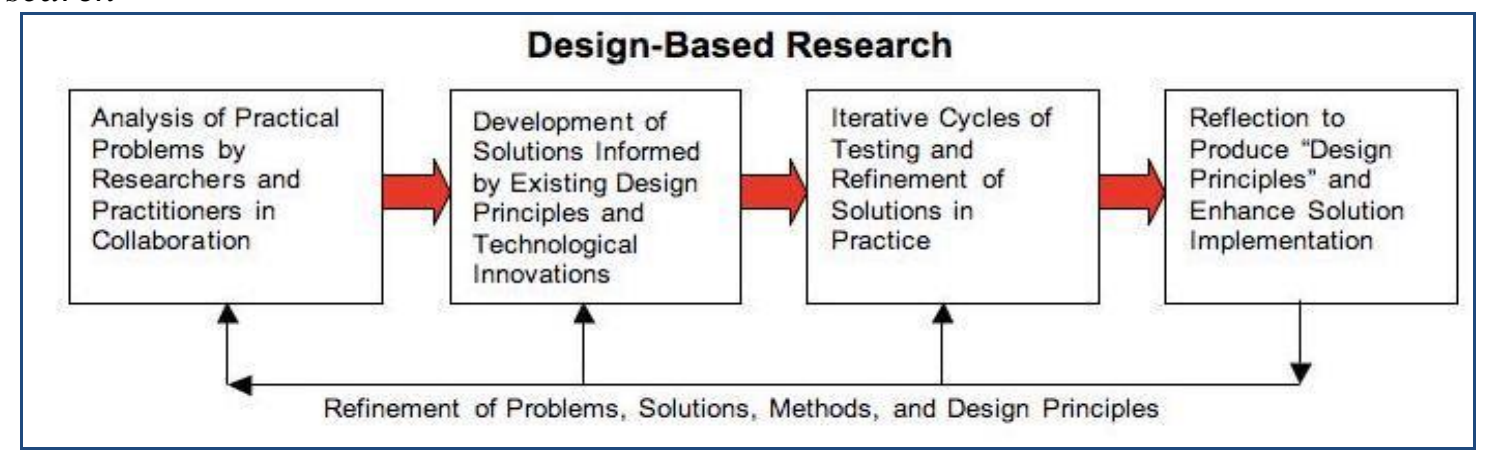

Source:(Reeves, 2006)

The project is guided by an overall research question and three secondary questions. The overall research question is:

How can ethical responsibility in the design of technologies be enhanced in the IS curriculum?

In order to support the answering of the main research question, the following sub-questions are included to explore the learning environment required in more depth.

- What principles related to ethical responsibilities in technology design can be found in the literature?

- How can these key principles inform the IS curriculum and pedagogy?

- What is the student experience of the intervention in raising their ethical responsibility?

This learning intervention will take place over three iterations for post graduate Information Systems students during the second semester in 2019 and for IS students in 2020. The design principles were piloted during an intervention in the first semester in 2019 for post graduate students in IS Strategy. This paper discusses the initial findings from this pilot study.

The design principles will apply to the layout of the course and students will be required to reflect on their process via a blog. Clear rubrics and direction will be provided to the students and they will have a process of peer review built in.

The incorporation of ethics and a futurist perspective will be the foundation of design principles in student projects. The students will be subjected to a design thinking process that incorporates a future focused perspective. The intention is to expand the principles of design thinking to include a wider perspective on the role of technology, responsibility and values. It is perceived that students will be exposed to ethics for a digital world within this process.

The modules will further incorporate scenario planning exercises in order to expose students to future studies, trend forecasting and experimentation. Students will be required to use multimedia in the process and the incorporation of art and drama will also be explored. 


\section{World Conference on Teaching and Education}

\section{8-20 October, 2019 Budapest, Hungary}

Students will be required to implement projects working in collaboration with industry and the suggestion is that they partner with an existing network of Small Medium and Micro Enterprises (SMMEs) to implement a working digital technology solution within their business.

\subsection{Data collection}

Data collection will be via the student blogs where the blogs will be analysed for patterns and perceptions from students regarding their experiences. Lecturer and peers must provide formative feedback to students on their blogs during the semester, and the formal assessment of all blogs occurs at the end of the semester. The analysis will occur during the semester to encourage students to be as candid as possible in their blogs and not to see it only as a mechanism of assessment.

The artefacts created by student teams will be a further source of analysis as well as all prototypes produced during the semester.

Feedback from entrepreneurs where relevant will also be obtained as a further source via a Google Forms questionnaire at the end of the semester. This may be followed up with an open ended interview to test certain perceptions.

\subsection{Data analysis}

A qualitative analysis of student blogs will take place where meanings and patterns will be identified pertaining to ethical principles and values developed within the process of design. The patterns will be analysed to study the impact of design principles on the course design in order to make changes to principles in following iterations where required.

The artefacts that students produce from their prototypes will be analysed to test the functionality thereof in terms of a future focused perspective embedded in ethical principles.

The process of making and deliberating within the teams will be a further focus of assessment to test the outcome of design principles.

For student teams engaging with entrepreneurs, a questionnaire followed by an interview (where required) with the entrepreneur will also be used for evidence of the development that took place and the presence of ethics, social justice and a future focused mind-set by student teams. The questionnaire will be designed using a Likert Scale and some open ended questions will be included to further test the overall outcome of projects.

\section{Results}

I have learned some valuable lessons in terms of how to conduct scenario planning and trend forecasting in future. It is vital to spend some more time prior to the actual exercise to stimulate future thinking by the students. They should be tasked to conduct an environmental scanning exercise looking the trends and mega trends that may impact the future. They need to be given some readings on this and guided in terms of what is meant by trends.

I assumed that the post graduate students will be more informed about the current Political, Economic, Environmental, Social and Technological situation within the world. They were exposed to this during the semester but require more scaffolding in terms of other areas besides technology futures. The teams ended up spending too much time on this part of the exercise and 


\section{World Conference on Teaching and Education}

\section{8-20 October, 2019 Budapest, Hungary}

we did not get to the very rich and creative stories that I was hoping for at the end of the process. I will allow more time for the process to unfold and not assume that students are attuned to their environment and what is happening in the world around them. They are very interested in technology but need some broader lenses in terms of their overall impact on society and the broader picture of what they would like their future world to be. The students did, however, indicate that they found the exercises to be very beneficial as indicated by the following replies from their student blogs.

It was fun connecting the future state of ICT capabilities and seeing what the outcome of using ICT can produce. It is amazing what benefits can be achieved with the digital era.DM

The new skills I have learnt during the course are a lot, from academic, social, interpersonal, innovation just to mention a few. Academically I learnt new content and the skills to do future planning. BM

I was hoping to generate more ideas and for the students to explore options more widely and not just stick to the familiar pattern of thinking about the future prospects of different world views. Incorporating exercises on emotional intelligence, ethical awareness and simulation games is also recommended. Students found that they benefited from this during the semester.

I also learnt that an empathy map is the key to getting to know your audience because it allows business owners to shift their focus from product-oriented production to customeroriented production. TT

She also made us take the EQ test. This test was so informative and insightful as we learnt that we are not always correct in our approach. $A B$

I think knowing your type of emotional intelligence or the way in which you handle situations can go a long way in finding what you need to improve about yourself, how you approach others and how you justify your actions. It is important to have an understanding about yourself for peace of mind and to enable you to find your life purpose or life path.

$M M$

I have a huge feeling that at the end of this module, I'm going to come out the other side of the pool an improved specimen. $M E$

It is recommended to bring the scenario planning exercises in from the start of the course to assist students to apply their minds. The scenario planning exercise can combine groups during the initial stages with the facilitator playing a central role. It needs to form part of the final assessment but also be an exercise in the student blogs where students need to reflect on their own future world views and their feeling about the future in terms of sustainability, climate change, ethics and technology.

\section{Discussion of updated design principles}

The findings from the pilot study resulted in a review of the draft design principles and updated design principles to be tested and further refined in the subsequent iterations during 2019 and 2020.

Table 2: Updated design principles. 


\begin{tabular}{|c|c|}
\hline Draft design principles & Final design principles \\
\hline $\begin{array}{l}\text { Implement a formal } \\
\text { process of reflection via } \\
\text { blogs }\end{array}$ & Implement a formal process of reflection \\
\hline $\begin{array}{l}\text { Reflection on refinement } \\
\text { Students can reflect in other } \\
\text { ways as well and should not } \\
\text { be limited to blogs. They } \\
\text { should also have the } \\
\text { opportunity to have a team } \\
\text { blog where they record their } \\
\text { progress or a Google Site that } \\
\text { they update. } \\
\text { The guidelines in rubrics } \\
\text { need to be more explicit in } \\
\text { terms of what is meant with } \\
\text { futurist design principles and } \\
\text { scaffolding need to be } \\
\text { provided via more exercises } \\
\text { in class to create an } \\
\text { awareness of a future wider } \\
\text { than just that of new } \\
\text { technologies. The good, the } \\
\text { bad and the ugly needs to be } \\
\text { unpacked in a collective } \\
\text { manner between teams and } \\
\text { with the lecturer/facilitator. }\end{array}$ & $\begin{array}{l}\text { - } \\
\text { - } \quad \text { Prudents should be given the option to do this via a blog } \\
\text { Provide guidelines via rubrics on content to be included } \\
\text { in the reflections, such as weekly discussions on what } \\
\text { has been learned, what was the good the bad and the } \\
\text { ugly. Include exercises to make students more } \\
\text { comfortable with innovation and experimentation via } \\
\text { creative expression. For example reflections on futurist } \\
\text { scenarios and finding solutions for issues focused on } \\
\text { equality, sustainability, social justice and ethics. } \\
\text { Include tasks where students need to reflect on the } \\
\text { challenges that technological and environmental } \\
\text { transformations are posing for their own future. They } \\
\text { need to question their future roles as designers of } \\
\text { complex systems for example the power distribution } \\
\text { across human, machines, and natural systems. } \\
\text { A further exercise should be critical reflection on the } \\
\text { question of how societies should govern technologies } \\
\text { that pose ethical challenges and may have undesirable } \\
\text { influences on societal priorities. Assess the reflection } \\
\text { process using clear guidance in the rubric in terms of } \\
\text { expected outcomes. } \\
\text { Lecturer and peers must provide formative feedback to } \\
\text { students on their reflections during the semester, and the }\end{array}$ \\
\hline
\end{tabular}

formal assessment of all reflections (blogs) occurs at the end of the semester. 


$\begin{aligned} & \text { Incorporate a future } \\ & \text { oriented agenda }\end{aligned}$
This should be built into the
course design from the onset
and the second lecture should
be a scenario planning
exercise to introduce the
concept as a collective to the
entire class. The exercise
should focus on something
more general such as the
future of education and not be
limited to the impact of
technology only.

Incorporate futurist thinking mechanisms

- Apply foresight tools, such as horizon scanning and scenario planning in the curriculum. It is recommended to start the course with a scenario planning exercise and codesign a preferred future for education to introduce the concepts.

- Students need to do research on future trends and reflect on their interpretation/s thereof via their blogs, vlogs or group websites.

- The final project should incorporate scenario planning for the client's business.

\section{Provide opportunities for students to find their own solutions}

Extra bullet point to be included:

- Use lecture times to expose students to issues via videos, guest lectures and Ted Talks. Allow teams to explore, investigate and present findings. The future can be better confronted by opening our minds and learning to consider different viewpoints.

\section{Provide opportunities for students to find their own}

\section{solutions}

- When the students struggle and sometimes fail to find a solution, they gain a deeper insight into the problem and its elements.

- $\quad$ Structure the class to enable each team to work together, i.e. around a table or in a breakaway venue if possible.

- Do not put too much structure in place; some background material ought to be provided prior to the lecture via, for example, voiceover PowerPoint and videos, and lectures can be used to practically explore this further and incorporate the relevant areas into capstone projects.

- Allow students to discover their own answers by accessing several different sources and experimenting with different techniques to become comfortable with pivoting, adapting and changing.

- Students ought to play a large role in shaping the course by setting their own deadlines, determining leadership roles and managing group dynamics.

\section{New principle to be added}

\section{Cultivate ethical designers}

- $\quad$ Make students aware of their design imprint on society and take them through the process of design thinking, where they start with user needs and combine user stories with empathy maps and/or personas. They need to become aware of the wider imprint that they have on 


\begin{tabular}{|l|l|}
\hline society and that the user can be human or nonhuman \\
with the systemic implications thereof. \\
They then follow the process of prototyping, testing and \\
repeating the process where required. \\
Students need exposure to their overall impact in the \\
design process with entrepreneurs to consider ethical \\
implications such as justice, equity, privacy, autonomy, \\
safety and security, sustainability and wellbeing \\
amongst others. The concept of responsible innovation \\
should be embedded in the design rollout (van den \\
Hoven 2017). To enable this, students will require \\
exposure during lecture times in the form of readings, \\
videos, blogs and/or guest lectures that cover these \\
topics. \\
Both the lecturer and the students need to learn to \\
embrace the uncertainties and open-ended nature of \\
design problems and to learn to accept failure. Lecturer \\
should stress the importance of productive failure and \\
assist students to correct prototypes and encourage them \\
to try new things and new ways of doing.
\end{tabular}

\section{Conclusion}

The paper presented findings from a pilot study of a DBR project that explores the design of teaching and learning principles that will foreground an ethic of responsibility among Information Systems (IS) students. In the paper, an outline of the draft design principles initially developed from a review of the literature and consultation with other stakeholders are discussed. These principles were developed to assist in the preparation of IS students to become ethical designers via their engagement in responsible research and innovation.

The draft principles were tested in a pilot study to test their robustness and were subsequently further refined for testing and refinement in subsequent iterations over a two year period. 


\section{World Conference on Teaching and Education}

\section{8-20 October, 2019 Budapest, Hungary}

\section{References}

Brynjolfsson, E., Mitchell, T. \& Rock, D. 2018. What Can Machines Learn, and What Does It Mean for Occupations and the Economy? AEA Papers and Proceedings. 108:43-47.

Gibson, K., Bird Rose, D., \& Fincher, R. (Eds.). (2015). Manifesto for living in the Anthropocene. Brooklyn: Punctum books.

Herrington, J. \& Reeves, T.C. 2011. Using design principles to improve pedagogical practice and promote student engagement. ASCILITE 2011 - The Australasian Society for Computers in Learning in Tertiary Education. 594-601.

Monteiro, F., Leite, C. \& Rocha, C. 2018. Ethical education as a pillar of the future role of higher education: Analysing its presence in the curricula of engineering courses. Futures. (February):0-1.

Mulvenna, M.D., Boger, J., Bond, R.B. 2017. Ethical by Design: A Manifesto. In Proceedings of European Conference on Cognitive Ergonomics 2017 (ECCE 2017), Umeå, Sweden, September 19-22, 2017, 4 pages.

Philbeck, T., Davis, N. \& Engtoft Larsen, A.M. 2018. Values, Ethics and Innovation: Rethinking Technological Development in the Fourth Industrial Revolution. Geneva, Switzerland.

[Online].

Available: http://www3.weforum.org/docs/WEF_WP_Values_Ethics_Innovation_2018.

Price, R., Matthews, J. \& Wrigley, C. 2018. Three Narrative Techniques for Engagement and Action in Design-Led Innovation. She Ji: The Journal of Design, Economics, and Innovation. 4(2):186-201. DOI: 10.1016/j.sheji.2018.04.001.

Reeves, T. C. 2006. Design research from a technology perspective. In Educational design research. J. van den Akker, K. Gravemeijer, S. McKenney \& N. Nieveen, Eds. London: Routledge. 52-66.

Tassone, V.C., O’Mahony, C., McKenna, E., Eppink, H.J. \& Wals, A.E.J. 2018. (Re)designing higher education curricula in times of systemic dysfunction: a responsible research and innovation perspective. Higher Education. 76(2):337-352.

Van den Hoven, J. 2017. Ethics for the Digital Age: Where are the Moral Specs? In Proceedings of the 11th European Computer Science Summit: Informatics in the Future. H. Werthner \& F. van Harmelen, Eds. Vienna: Springer. 65-76.

Walsham, G. 2012. Are we making a better world with ICTs? Reflections on a future agenda for the IS field. Journal of Information Technology. 27(2):87-93. 